\title{
Right to Reply: Using Patient Complaints and Testimonials to Improve Performance in the NHS
}

Droit de réponse: Les plaintes et les témoignages de patients comme instruments d'amélioration de la performance du NHS

\section{Louise Dalingwater}

\section{(2) OpenEdition}

\section{Journals}

Electronic version

URL: http://journals.openedition.org/rfcb/4422

DOI: $10.4000 /$ rfcb. 4422

ISSN: 2429-4373

\section{Publisher}

CRECIB - Centre de recherche et d'études en civilisation britannique

Electronic reference

Louise Dalingwater, « Right to Reply: Using Patient Complaints and Testimonials to Improve Performance in the NHS », Revue Française de Civilisation Britannique [Online], XXIV-3 | 2019, Online since 30 August 2019, connection on 04 September 2019. URL : http://journals.openedition.org/ rfcb/4422; DOl : 10.4000/rfcb.4422

This text was automatically generated on 4 September 2019

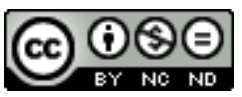

Revue française de civilisation britannique est mis à disposition selon les termes de la licence Creative Commons Attribution - Pas d'Utilisation Commerciale - Pas de Modification 4.0 International. 


\title{
Right to Reply: Using Patient Complaints and Testimonials to Improve Performance in the NHS
}

Droit de réponse: Les plaintes et les témoignages de patients comme instruments d'amélioration de la performance du NHS

\author{
Louise Dalingwater
}

\section{Introduction}

\begin{abstract}
A health service that does not listen to complaints is unlikely to reflect its patients' needs. One that does will be more likely to detect the early warning signs that something requires correction, to address such issues and to protect others from harmful treatment. (Robert Francis Q C, Staffordshire enquiry) ${ }^{1}$
\end{abstract}

Carl Rogers is believed to have developed the first person-centred approach to health care in the area of psychotherapy ${ }^{2}$. Then, in the late 1970s, the American psychiatrist George Engel promoted a biopsychosocial model of health; that is, a person-centred model of health care. Neither of these approaches have specifically been adopted by the National Health Service today but they have helped to put focus on the need for empathy and for the professional to be prepared to suspend judgment and appreciate the service user's or patient's perspective ${ }^{3}$. Person-centred care has become a particularly prominent part of national health policy and local practice in recent years. In 2013, the Department of Health declared a shared commitment to making 'person-centred coordinated care' a key part of health and social care delivery ${ }^{4}$.

A number of different methods are currently in place within the NHS which actively encourage patients to judge the provision of health by sharing their experiences of care and treatment, completing surveys, etc. Testimonials are also a way of evaluating the 
provision of health care and are posted regularly on NHS websites (Patient Opinion, NHS Choices, etc.), and also on special care and charity websites. Stories told by individuals from their own perspective and in a health care setting can provide health care providers with an opportunity to understand experiences of care and to gain an insight into what could be done to improve the patient's experience. Providing an outlet for patients to complain can be a useful way of not only ensuring that individual rights to quality health care are respected but also of increasing awareness of safety-related problems within health organisations, or various problems relating to health care delivery. Traditional evaluation and monitoring of health care systems are not necessarily sensitive to specific failures in care and so patients and families can provide valuable insights into health care delivery $^{5}$.

All NHS health care organisations in England and Scotland must carry out postal surveys to give patients a chance to air their views on their recent experience of health care. These national surveys aim to compare results locally and should enable policy makers and regulators to examine overall performance of health services. However, such information and other data on user experiences are not currently well aggregated or used to drive improvements in health care delivery. So, while the right to reply and using patients' experiences and/or complaints might be a way to improve care, this paper underlines a number of difficulties in collating and effectively using such information. It starts by underlining the drivers behind initiatives to give patients or service users a voice in health care provision. It then gives an extensive but not exhaustive review of NHS and nationwide initiatives to take account of the user/patient's perspective on health care provision. It also underlines the essential weaknesses in using patients' complaints and care testimonials to judge the quality of care and drive improvements. Finally, it uses a case study of the Mid-Staffordshire Hospital Trust negligent care scandal of the period 2005 to 2008 to illustrate why a patient-led approach to monitoring care provision is essential but difficult to implement in practice.

\section{Drivers for collating patients' views and correctly processing complaints}

Since there has been an increase in the reporting of adverse effects, that is people dying or being seriously injured, it would seem important to take criticisms of health services seriously. Indeed 400 people have been reported as dying or being seriously injured after the use of medical devices in the NHS, 10,000 people had adverse reactions to drugs prescribed by NHS consultants and 1150 people committed suicide despite being in contact with NHS mental health services. The NHS receives roughly 28000 written complaints a year on clinical treatment in hospital and pays $£ 400$ million on clinical negligence claims ${ }^{6}$. Adverse effects have been reported to be higher in Great Britain (around 10\%) than France, for example (3.7\%) ${ }^{7}$.

Apart from fatal cases, a number of other reasons for complaints have been put forward including lack of information, lack of compassion, lack of dignity and care, staff attitudes and lack of resources ${ }^{8}$. The Complaints Task Force and NHS management documents support the thesis that complaints can enable managers to manage risks and threats better (risk management programmes for example). Complaints can be used in order for providers to understand how users view their services and identify issues which need to be dealt with. They can also be used to rectify past mistakes and enable services to be put 
right in the future. Well-handled complaints can increase trust in patients and identify adverse effects which might not have been detected otherwise. Patient complaints and testimonials can capture failures in quality or other questions (such as dignity) which cannot be measured through traditional metrics. As an aggregate measure and provided they are correctly processed, they can reveal problems in health care provision.

A series of investigations and reports which examine patient complaints and testimonials on care emphasise the importance of using such material to drive improvements in health care: the Wilson Report 'Being Heard' of May 1994, the Public Law Project's report 'Cause for Complaint?' of September 1999 and the York Health Economics Consortium's report (the York Report) published in March 2001 are just some examples of work in this area. These reports have been instrumental in improving the complaints procedure and the development of a person-centred or patient-centred approach within the NHS.

\section{NHS and nationwide initiatives to take into account the user's perspective}

Indeed, the complaints system has been gradually improved, especially from 1996 onwards. Since 1985, the Hospital Complaints Procedure Act set forth a host of national procedures for hospitals to deal with complaints. Complaints regarding GPs are made to the Family Health Services Authority (FHSA). However, from the 1990s, complaints procedures were improved because of criticism of the lack of effective treatment of grievances. The Wilson committee was set up to investigate and suggest improvements to the complaints system and, in 1994, a more simplified two-stage structure system for grievances was introduced. In 1996, in line with the patient-centred approach, a unified complaints system was introduced for hospitals, community health services and family services in the NHS. Dissatisfaction with acute, primary or secondary health care should first be addressed to the trust, CCG or other care provider with a view to resolving the issue as quickly as possible (by a Local Resolutions Unit). However, if the complaint is unresolved, it is then addressed to an Independent Review Panel. The panel must investigate the complaint, write a report and make comments and recommendations to redress the grievance and/or make recommendations for service improvements. If this review is not satisfactory, then the complainant can refer the matter to the Health Service Commissioner at NHS England ${ }^{9}$. The latter then publishes an annual overview and six-monthly reports on investigations into complaints with possible recommendations for action. Beyond providing a system for complaints, the NHS also actively encourages patients to give their views on the health system.

The NHS Patient Experience Framework underlines that patient experience is one of the central outcomes to be considered along with effectiveness and safety ${ }^{10}$. The NHS Future Forum called for the establishment of new metrics to bring together already existing data on patient experience. The NHS has taken several initiatives to enable the patient to share his or her experience of health care provision and in so doing evaluate the quality of care provided. The NHS Constitution and the Health Act of January 2010 impose a legal obligation on service providers to take into account the decisions and actions of patient experience. The NHS Outcomes Framework also makes clear that the provision of a good experience of care for patients is a fundamental part of the NHS. The NHS Patient Experience Framework sets forth a definition and measurement of patients' experiences. 
Patient-reported experience measures (PREMs) and patient-reported outcomes (PROMS) are also currently used by NHS providers.

The Department of Health has also been active in promoting a patient or person-centred approach. The 2010 White Paper, Equity and Excellence: Liberating the NHS ${ }^{11}$ underlines that there should be more emphasis on improving people's experience of health care. More recently, in 2013, a Department of Health Review Team also set up a dedicated postal and email address for people to send accounts and experiences of health care. They received 2500 letters and emails and the team reviewed the data. Seven public engagement events were also held. The review team visited nine NHS hospitals and one hospice to meet up with complaints managers, frontline staff and board members ${ }^{12}$.

The Picker Institute underlined nine quality dimensions which it discovered through its work were most important to patients and families: fast access to reliable health advice, effective treatment delivered by trusted professionals, participation in decisions and respect for preferences, clear, comprehensible information and support for self-care, attention to physical and environmental needs, emotional support, empathy and respect, involvement of, and support for, family and carers and finally continuity of care and smooth transitions ${ }^{13}$. There have been a number of attempts to monitor the quality of care through the use of Picker surveys. For example, Southampton University Hospitals Trust asked patients to complete surveys on these 9 key quality dimensions. Every month such results are shared across the hospital to "put patient experience at the centre of quality". It has already helped the trust to recognise and deal with problems such as improving information given to patients ${ }^{14}$. Some hospital trusts and GP practices routinely seek out more general feedback: how long a patient has been waiting, quality of care, etc. Many trusts also have a specialised complaints department. Moreover, national bodies support quality improvement through patient input such as HealthWatch England, Citizens Advice, Patients Association, Actions for Victims of Medical Accidents, the Consumers Association, National Voices, etc.

In England, an annual General Practice Patient Survey is carried out to collate information on people's experience of primary care. It surveys five million people each year. For hospitals, a National Adult Inpatient Survey has been in place since 2002 which surveys 600,000 patients every year ${ }^{15}$. The results of this survey have been used to lead policies to improve patient care.

The UK also has a number of websites where patients and family members can post their stories about NHS care experiences. For example, Patient Opinion invites patients and families to post short anonymous stories and 45,000 testimonials are available on the website. Once the stories are published, the website administrators contact the relevant health organisation giving them an opportunity to post a reply. The Francis Report (2013) claimed that this site had the potential to improve the quality of care. NHS Choices is another website which provides patients with the opportunity to give accounts of service provision, particularly in a hospital setting. Comments often relate to human errors, incorrect medical recording and medical errors, etc. ${ }^{16}$.

However, there are a number of problems related to using such data and accounts of care to drive improvements in care provision ${ }^{17}$. 


\section{Obstacles to using patient complaints and testimonials to improve NHS healthcare provision}

There are essentially three types of obstacles to using patient complaints and testimonials to improve health care provision. The first is the reliability of the data itself, the second is the ability to aggregate such information to improve health care provision nationwide and the third is related to flaws in the complaints system.

\section{Reliability of data}

National surveys are not necessarily adapted sufficiently enough to the local situation or local needs. Researchers Wright et al. carried out a study to assess whether such performance evaluations through questionnaires were reliable ${ }^{18}$. The conclusions of their study showed that while such evaluations may give formative feedback on a doctor's professional practice, because of the subjective nature of the feedback, such surveys should not be used in isolation. Moreover, it depends how the questions are formulated. It has been found that responses to closed-ended questions usually give positive answers about care whereas open-ended questions tend to give negative results. This is known as the "leniency effect' 19 . The problem with open access websites is that it is difficult to verify and check the validity of the stories and responses. Some closed access systems also exist and in these systems the patients are sent an invitation to share their care experience, but they must register to share their stories so such systems might be more reliable.

The problem with using complaints and/or testimonials to improve the system overall is that patient complaints are not necessarily a systematic sign of failure. The other issue is that they are often emotive and specific to individual health care professionals. Patients might complain without taking into account wider pressures (staff workloads for example) meaning that they are unable to analyse other factors influencing the provision of health care. When things go wrong, the response is often to identify an individual or individuals to blame. But while individual health care workers should be called to account for their actions, in a large number of cases, the failures stretch beyond the individuals to the system at large. In separate studies, Allsop ${ }^{20}$ and Lloyd-Bostock and Mulcahy ${ }^{21}$ underline the essential difficulties of using narratives to drive change in health care provision. They note that such accounts contain quite a lot of personal information which might not be relevant to, or comparable with, other cases. They underline that the strength of the emotions may actually not communicate relevant grievances. When a loved one has suffered from a serious illness, carers and family tend to look for someone to blame.

\section{Lack of an aggregated data system}

Moreover, there is no systematic nationwide policy in place or standard measure to collect people's experience of health care in the NHS. The methodologies used to aggregate patients' complaints are often inconsistent or do not aggregate data sufficiently to give optimal depth to complaints. Data thus remains at a raw and experimental level, unstandardized and difficult to compare. Collection of data for 
primary care is considered to be even more inconsistent. So, while there would seem to be a move towards giving patients opportunities to complain and seek redress, there are limits to the processing and effective use of such material.

\section{Flaws in the complaints system}

In terms of criticisms of the complaints procedure, an investigation led by Dame Janet Smith in the Fifth Report of the Shipman Inquiry, and published in 2004, found that complaints were not always investigated properly, adequate explanations were not given, there was a failure to take account of the inherent imbalance of power between health care professionals and patients and there was sometimes patients' fear of retribution if they spoke up $^{22}$. There was also a certain lack of impartiality in organisations investigating their own conduct, and a lack of accountability. The charity Mencap found for example that when a death or serious incident occurs, complaints are investigated by members of NHS staff working within the same trust or CCG where the incident occurred. Investigators might even be from the same unit or specialty ${ }^{23}$. This represents a serious conflict of interest and impartiality in the investigation. The Wilson committee also underlined some inherent difficulties for complainants using the NHS complaints procedures. First, complainants find it difficult to make their views known, but they often fail to receive a correct response.

The charity Mencap emphasised that the complaints process is slow, bureaucratic and defensive. Not only do families have to wait years to obtain justice for death caused by mistreatment or negligence, but the NHS does not seem to learn from failures and take steps to avoid deaths or serious incidents in the future ${ }^{24}$. The charity MIND discovered that patients find it hard to identify to whom they should complain and other inherent difficulties in navigating the complaints systems ${ }^{25}$. This results in a high number of families not filing for redress ${ }^{26}$. HealthWatch England describes the complaints system as "off-putting, complex and slow"27. Mulcahy and Tritter's 1993 study of 1640 households found that $60 \%$ of those who were dissatisfied with health services did not lodge a serious complaint because of the lack of knowledge of the complaints system, low expectations, feelings of gratitude, fear of retribution, deference to health professionals and life events 28. When complaints are made it is often hard for them to be followed through: patients and families complain about a lack of responses or follow up to phone calls, impersonal letters of reply, not being kept informed of progress, inadequate replies, the length of time ${ }^{29} \ldots$. Mulcahy and Tritter also reported that people often complain about the complaints procedure because of incomplete explanations, dismissive letters, "pseudoapologies", technical language and defensive responses ${ }^{30}$. Alsop and Mulcaly, in their analysis of patients' complaints, found that little attempt was made to translate technical or defensive material into simpler language ${ }^{31}$.

So, while data is collected, there is no systematic or reliable way of identifying lapses in standards of care, analysing them and learning from mistakes in order to introduce change. Indeed, a Department of Health report found that while individuals may learn from change, there is no apparent collective learning process in the $\mathrm{NHS}^{32}$. The inability to learn from incidents can be explained by a number of institutional causes: rigidity of belief, values, lack of corporate responsibility, ineffective communication, a tendency for scapegoating, difficulties in understanding complex events ${ }^{33}$. 
To sum up, the key problems identified in using patient views and complaints to improve the quality of services provision include the lack of consensus on what to report, an absence of proper linkages between reporting systems, inability to make the best use of available information, lack of analysis across different systems and inability to apply recommendations across the board. Both testimonials on care and complaints lodged by patients have the potential to drive change but the system is currently difficult to put in place. The following case study is an illustration of the importance of developing a patient reporting system, but also the current failures to do so inherent in many NHS institutions.

\section{The Mid-Staffordshire scandal ${ }^{34}$}

The Mid-Staffordshire hospital trust crisis is an example of why it is important to use patients' surveys, testimonials and complaints to detect failures in care and remedy them, but also the difficulties in processing complaints effectively. The specific example of Stafford Hospital is very telling because it is an appalling tale of negligence in the provision of NHS hospital care and an illustration of why current care evaluation systems are not necessarily the most effective way of assessing quality of care in NHS institutions. It also underlines the essential role that patients' complaints and stories can and should play in driving up the quality of care in the NHS. Substandard levels of care were uncovered at Stafford hospital:

mainly because of the persistent complaints made by a very determined group of patients and those close to them. This group wanted to know why they and their loved ones had been failed so badly. (Francis, 2013, Executive summary, p7) ${ }^{35}$

From 2009 to 2013, a total of 5 investigations and official reports were published, the most conclusive and complete being a final report written in 2013, as a result of a full public inquiry by Sir Robert Francis QC. The scandal came to light when the Healthcare Commission, which compiles mortality rates, became aware of an unusually high number of deaths at Stafford hospital. While the Healthcare Commission already had concerns about the hospital at this point, the investigation was triggered when Cure the NHS, an association of relatives and patients who had experienced substandard levels of care at Stafford Hospital (leading to deaths in some cases), contacted the Healthcare Commission with their concerns and were asked to write a report ${ }^{36}$.

The Commission then carried out an investigation between March 2008 and October 2008 interviewing almost 300 people, including 100 patients. The Commission announced that they were leading an investigation and 103 patients and families contacted this organisation spontaneously. Within this group, 99 were critical or had an experience of poor care at Stafford hospital. The Healthcare Commission's annual survey of inpatients also showed that the trust was in the bottom $20 \%$ for performance for 39 out of 62 criteria ${ }^{37}$. The reasons given for these failures were numerous. The Healthcare Commission reported that the foundation trust had not set up an effective system to admit and manage patients or monitor outcomes. The hospital trust's board and senior leaders did not acknowledge the high rates of mortality and concluded that it was due to data problems or errors. Failures to diagnose and treat patients in A\&E, inadequate staffing levels and inexperienced staff were also reported ${ }^{38}$.

The Healthcare Commission report was then followed by an independent inquiry led by Robert Francis QC, a barrister who had led many clinical negligence claims in the past. 
The results of the first public inquiry were published in 2010 and compiled evidence from over 900 families $^{39}$. This report focused on failings in the trust itself. It reported very basic elements of neglect in the provision of hospital care: patients not washed for up to a month, food and drink placed out of patients' reach, family members having to make sure that they arrived at meal times to feed them, neglected hygiene, etc. Families removed used bandages and dressings from public areas and cleaned the toilets themselves because they were in such a dreadful state. Patients were left for hours in soiled sheeting or forgotten on commodes. Misdiagnosis was also common during the period 2005 to 2008 and patients went for hours without food, drink or medication, inexperienced doctors were left on their own on night shifts and receptionists with no medical experience manned the Accident and Emergency desk ${ }^{40}$.

The first public inquiry of July 2010 also investigated why traditional measures of health provision had failed to detect such poor care provision. Indeed, none of the national and local institutions: the local Strategic Health Authority, the local Primary Care Trust, Monitor (the Independent Regulator of NHS Foundation trusts) and the Care Quality Commission had detected failures in the quality of care. Many of these bodies had been set up under the New Labour government to better detect failures of care.

Members of the local campaign group Cure the NHS then called for a public inquiry to understand failings in the broader context of the NHS and to avoid a repeat of such incidents in other NHS trusts. They complained that the independent inquiry published in 2010 was neither wide enough in scope nor transparent ${ }^{41}$. A full public inquiry was launched in 2010 and published in 2013.

The final 2013 report revealed that there was a chronic shortage of staff, especially nursing staff and morale was so low that some showed a lack of compassion towards patients. Staff who wished to report the conditions were deterred from doing so because of bullying. The Francis report found that the reason behind the understaffing and lack of essential equipment on the wards was that there had been staff cuts in the 2006-7 period to try to make savings of $£ 10 \mathrm{~m}$ in order for the hospital to gain Foundation Trust status ${ }^{42}$. Indeed, at that time the granting of Foundation Trust status gave a hospital more autonomy to run as an independent corporation, accountable to local communities rather than the central government. It also meant more budget flexibility:

This failure was in part the consequence of allowing a focus on reaching national access targets, achieving financial balance and seeking foundation trust status at the cost of delivering acceptable standards of care. (Francis report, 2013, Executive summary, $\mathrm{p} 3)^{43}$

Sir Robert however underlined that much of the blame should be placed on the trust's ruling board. The action taken to investigate and try to resolve concerns was inadequate and lacked a sense of urgency. This is where the importance of patients' complaints and patient and family testimonials on care play a major role. The various quality control reports from outside bodies including the Mid Staffordshire Health Care Commission had given the hospital "good" ratings. However, the trust's ruling board failed to take into account the patients'/families' complaints and a number of testimonials compiled by the hospital according to national requirements. In addition, according to a recent report, 64 people wrote letters of complaint to the Department of Health about substandard care at the hospital trust between August 2005 and March 2009, but department officials failed to investigate complaints ${ }^{44}$. Sir Robert also underlined that staff who tried to raise concerns were not listened to and/or bullied into leaving their jobs. For example, a staff nurse at 
Stafford Hospital who reported a complaint about waiting times was bullied. The trust refused to take the complaint seriously and the Royal College of Nursing advised her to "keep her head down"45. Other external reports should also have been taken into account. In 2004, the trust was re-rated by the Commission for Health Improvement as a zero-star trust and a 2007 Royal College of Surgeons report described the surgical department as "dysfunctional".

Both of Sir Robert's reports were particularly critical of the failure of senior figures at the hospital and external health quality monitoring bodies (mentioned above) to collate, analyse and take patients' complaints into consideration. Sir Francis thus recommended, among other things, that the evaluation system needed to be improved:

Develop and share ever improving means of measuring and understanding the performance of individual professionals, teams, units and provider organisations for the patients, the public, and all other stakeholders in the system ${ }^{46}$. (Francis, 2013, Executive summary, p5)

The final 2013 report focused on investigating why the system of national inspection had failed. He underlined how important it was to take patients' and families' grievances into account within the evaluation process:

This was a failure of the trust first and foremost, but it was also a national failure of the regulatory and supervisory system, which should have secured the quality and safety of patient care. Why did it have to take a determined group of families to expose those failings and campaign tirelessly for answers? (Francis, 2013, Executive summary, p.9 $)^{47}$

It points to why ultimately more needs to be done to use patients' complaints and stories effectively in a more coherent way.

\section{Conclusion}

The Stafford Hospital example of failure of care shows how important it is to monitor quality care not only from external sources but from internal sources, especially patients and family. The introduction of Clinical Governance and a whole number of bodies of external evaluators to detect failures in care have not been sufficient to detect shortcomings. There have been recent attempts to implement a more effective complaints system in the NHS and processes to enable patients, family and staff to evaluate and report failings in care. It would seem however that a really effective nationwide system whereby staff and patients can freely air their views without fear of reprisal still has a long way to go.

Louise Dalingwater is Professor of British Politics at Sorbonne-Université in Paris. Her current research focuses on health services and wellbeing in the United Kingdom. Recent publications include a book on the NHS in print and several book chapters. She has also authored articles in academic journals including in Interventions économiques, The International Journal of Health, Wellness and Society, and Auto/biography review. 


\section{BIBLIOGRAPHY}

Allsop, Judith, “Two Sides to Every Story: Complainants' and Doctors' Perspectives in Disputes about Medical care in a general practice setting", Law and Policy 16, 1994, pp.149-84.

Allsop, Judith and Linda Mulcahy, "Dealing with Clinical Complaints", Quality in Health Care 4, 1994, pp. 135-143.

Calkin, Sarah, "Ten Frequently Asked Questions: What is the Francis Report", Nursing Times, 31 January 2013, <https://www.nursingtimes.net/news/reviews-and-reports/francis-report/10frequently-asked-questions-what-is-the-francis-report/5054230.article>.

Cure the NHS, "About Cure the NHS", 2018, <http://www.curethenhs.co.uk/about-cure-the-nhs/ $>$.

Department of Health, Department of Health, A Review of the NHS Hospital's Complaints System: Putting Patients Back in the Picture (London, HMSO, 2013).

Department of Health, Equity and Excellence: Liberating the NHS (London, HMSO, 2010).

Department of Health, An Organisation with a Memory (London, HMSO, 2000).

Department of Health, A First Class Service: Quality in the New NHS, 1 July 1988, HSC 1998/113, (London, Crown, 1998).

Dominiczak, Peter and Mason, Rowena, "More than 60 Mid Staffordshire hospital complaints to Government ignored”. The Telegraph, 24 March 2013, <https://www.telegraph.co.uk/news/ politics/9951218/More-than-60-Mid-Staffordshire-hospital-complaints-to-Governmentignored.html>.

Francis, Robert, Robert Francis Inquiry report into Mid-Staffordshire NHS Foundation Trust, HSC 1998/822 (London, Crown, 2010).

Francis, Robert, Report of the Mid-Staffordshire NHS Foundation Trust Public Inquiry, HC 947 House of Commons (London, Stationery Office, 2013).

Guiliani, Camila, Nathalie Gault,Valia Fares, Jérémie Jegu, Sergio Eleni dit Trolli, Julie Biga and Gwenaelle Vidal-Trecan, “Evolution of Patients' Complaints in a French University Hospital : Is There a Contribution of a Law Regarding Patients' Rights?” BMC Health Services Research 9: 141, 2009, <https://bmchealthservres.biomedcentral.com/articles/10.1186/1472-6963-9-141>.

Healthcare Commission, Investigation into Mid Staffordshire NHS Trust Foundation Trust (Summary Report) (London, Healthcare Commission, 2009).

Health Foundation, Measuring Patient Experience (London, Health Foundation, 2013).

Healthwatch England, Healthwatch England Annual Report 2015/6: Every Voice Matters, 2016.

Lloyd-Bostock Sally Mulcahy Linda, “The Social Psychology of Making and Responding to Hospital Complaints: An Account Model of Complaint Processes", Law and Policy 16: 123-47.

Mencap, Death by Indifference (London, Mencap, 2007).

Mulcahy, Judith and Jonathan Q. Tritter, Dissatisfaction, Grievances and Complaints in the NHS, A Report to the Department of Health (London, HMSO, 1993) 
Picker's Institute, Core Domains for Measuring Inpatient Experience of Care (Picker Institute Europe, Oxford, 2009).

Reader, Tom, Gillespie, Alex and Roberts, Jane, "Patient Complaints in Healthcare Systems: A Systematic Review and Coding Taxonomy", BMJ Journals 23: 8, 2013.

Rogers, Carl R. Client-centred therapy: Its current practice, implications and theory (Boston, Houghton Mifflin, 1951).

Wright, Christine, Suzanne H. Richards , Jacqueline J. Hill, Martin J. Roberts, Geoffrey R. Norman, Michael Greco, "Multisource Feedback in Evaluating the Performance of Doctors: The Example of the UK General Medical Council Patient and Colleague Questionnaires" Acad Med 87: 12, 2012, pp. 1668-1678.

\section{NOTES}

1. Robert Francis, Report of the Mid-Staffordshire NHS Foundation Trust Public Inquiry, HC 947 House of Commons (London, Stationery Office, 2013).

2. Carl R. Rogers, Client-Centred Therapy: Its Current Practice, Implications and Theory (Boston, Houghton Mifflin, 1951).

3. Health Foundation, Measuring Patient Experience (London, Health Foundation, 2013).

4. Department of Health, A Review of the NHS Hospital's Complaints System: Putting Patients Back in the Picture (London, HMSO, 2013).

5. Tom Reader, Alex Gillespie and Jane Roberts, "Patient Complaints in Healthcare Systems: A Systematic Review and Coding Taxonomy”, BMJ Journals 23: 8, 2013.

6. Ibid

7. Camila Guiliani, Nathalie Gault, Valia Fares, Jérémie Jegu, Sergio Eleni dit Trolli, Julie Biga and Gwenaelle Vidal-Trecan, “Evolution of Patients' Complaints in a French University Hospital : Is There a Contribution of a Law Regarding Patients' Rights?" BMC Health Services Research 9: 141, 2009, <https://bmchealthservres.biomedcentral.com/articles/10.1186/1472-6963-9-141>, consulted 16 December 2018.

8. Department of Health, A Review of the NHS Hospital's Complaints System: Putting Patients Back in the Picture, op.cit.

9. Department of Health, An Organisation with a Memory (London, HMSO, 2000).

10. Health Foundation, Measuring Patient Experience, op.cit.

11. Department of Health, Equity and Excellence: Liberating the NHS (London, HMSO, 2010).

12. Department of Health, A Review of the NHS Hospital's Complaints System: Putting Patients Back in the Picture, op.cit.

13. Picker's Institute, Core Domains for Measuring Inpatient Experience of Care (Picker Institute Europe, Oxford, 2009).

14. Picker's Institute, Core Domains for Measuring Inpatient Experience of Care, op.cit.

15. Health Foundation, Measuring Patient Experience, op.cit.

16. Ibid

17. Department of Health, An Organisation with a Memory, op.cit.

18. Christine Wright, Suzanne H. Richards, Jacqueline J. Hill, Martin J. Roberts, Geoffrey R. Norman, Michael Greco, "Multisource Feedback in Evaluating the Performance of Doctors: The Example of the UK General Medical Council Patient and Colleague Questionnaires", Acad Med 87: 12, 2012, pp. 1668-1678.

19. Health Foundation, Measuring Patient Experience. op.cit. 
20. Judith Allsop, “Two Sides to Every Story: Complainants' and Doctors' Perspectives in Disputes about Medical Care in a General Practice Setting", Law and Policy 16, 1994, pp.149-84.

21. Sally Lloyd-Bostock and Linda Mulcahy, "The Social Psychology of Making and Responding to Hospital Complaints: An Account Model of Complaint Processes", Law and Policy 16, 1994, pp. 123-47.

22. Department of Health, A Review of the NHS Hospital's Complaints System: Putting Patients Back in the Picture, op. cit.

23. Mencap, Death by indifference (London, Mencap, 2007).

24.

25. Department of Health, A Review of the NHS Hospital's Complaints System: Putting Patients Back in the Picture, op.cit.

26. Department of Health, A Review of the NHS Hospital's Complaints System: Putting Patients Back in the Picture, op. cit.

27. Healthwatch England, Healthwatch England Annual Report 2015/6: Every Voice Matters (London: Healthwatch, 2015).

28. Linda Mulcahy, and Jonathan Tritter, Dissatisfaction, Grievances and Complaints in the NHS, A Report to the Department of Health (London, HMSO, 1993).

29. Judith Allsop, and Linda Mulcah, "Dealing with Clinical Complaints", Quality in Health Care 4, 1994, pp. 135-143.

30. Linda Mulcahy and Jonathan Q. Tritter, Dissatisfaction, Grievances and Complaints in the NHS, A Report to the Department of Health, op.cit.

31. Judith Allsop and Linda Mulcahy, "Dealing with Clinical Complaints", op.cit.

32. Department of Health, An Organisation with a Memory. op.cit.

33. Ibid.

34. It is commonly reported as the Mid Staffs scandal because it involved a hospital run by Mid Staffordshire hospital trust. Once a hospital gained foundation hospital status before the 2012 Health and Social Care Act, it meant that it gained semi-independence from the Department of Health. The trust was thus able to make its own decisions about how the hospital should be run and what actions should be taken to keep costs down.

35. Robert Francis, Report of the Mid-Staffordshire NHS Foundation Trust Public Inquiry HC 947 House of Commons (London, Stationery Office, 2013).

36. Cure the NHS, "About Cure the NHS", 2018,

<http://www.curethenhs.co.uk/about-cure-the-nhs/> consulted 15 December 2018.

37. Healthcare Commission, Investigation into Mid Staffordshire NHS Trust Foundation Trust (Summary Report) (London, Healthcare Commission, 2009).

38. Healthcare Commission, Investigation into Mid Staffordshire NHS Trust Foundation Trust (Summary Report), op. cit.

39. Robert Francis, Robert Francis Inquiry report into Mid-Staffordshire NHS Foundation Trust, HSC 1998/822 (London, Crown, 2010).

40. Ibid.

41. Sarah Calkin, "Ten Frequently Asked Questions: What is the Francis Report", Nursing Times, 31 January 2013, <https://www.nursingtimes.net/news/reviews-and-reports/francis-report/10frequently-asked-questions-what-is-the-francis-report/5054230.article> consulted 10 January 2019.

42. See note 1 .

43. Robert Francis, Report of the Mid-Staffordshire NHS Foundation Trust Public Inquiry, op.cit.

44. Peter Dominiczak and Rowena Mason, "More than 60 Mid Staffordshire hospital complaints to Government ignored", The Telegraph, 24 March 2013, <https://www.telegraph.co.uk/news/ politics/9951218/More-than-60-Mid-Staffordshire-hospital-complaints-to-Governmentignored.html> consulted 18 January. 
45. Robert Francis, Report of the Mid-Staffordshire NHS Foundation Trust Public Inquiry, op.cit.

46. Robert Francis, Report of the Mid-Staffordshire NHS Foundation Trust Public Inquiry, op.cit.

47. Ibid.

\section{ABSTRACTS}

Within the British National Health Service (NHS), a number of different methods are currently in place which actively encourage patients to judge the provision of health by sharing their experiences of care and treatment, completing surveys, etc. Testimonials are also a way of evaluating the provision of health care and are posted regularly on NHS websites (Patient Opinion, NHS Choices, etc.), but also on special care and charity websites. Providing an outlet for patients to complain can be a useful way of not only ensuring that individual rights to quality health care are respected but also of increasing awareness of safety-related problems within health organisations, or various problems relating to health care delivery. However, such information and other data on user experiences are not currently well aggregated or used to drive improvements in health care delivery. So, while the right to reply and using patients' experiences and/or complaints might be a way to improve care, this paper underlines a number of difficulties in collating and effectively using such information. It uses a case study of the MidStaffordshire Hospital Trust negligent care scandal of the period 2005 to 2008 to illustrate why a patient-led approach to monitoring care provision is essential but difficult to implement in practice.

Un certain nombre de dispositifs sont actuellement en place au sein du système de santé britannique NHS, qui encouragent activement les patients à évaluer l'offre de soins de santé en partageant leurs expériences en matière de soins et de traitement, en remplissant des enquêtes, etc. Les témoignages sont également un moyen d'évaluer la prestation de soins de santé. Ils sont postés régulièrement sur les sites Web du NHS (Patient Opinion, NHS Choices, etc.), mais également sur d'autres sites consacrés à la santé. Donner aux patients un moyen d'exprimer librement leur contentement et leurs griefs peut être un moyen utile non seulement pour garantir le respect des droits individuels à des soins de santé de qualité, mais également pour sensibiliser davantage les organismes de santé aux problèmes de sécurité ou à divers problèmes liés à la prestation de soins de santé. Cependant, ces informations et d'autres données sur les expériences des utilisateurs ne sont actuellement pas bien agrégées ou utilisées pour améliorer la prestation des soins de santé. Ainsi, alors que le droit de répondre et de faire appel aux expériences et / ou aux plaintes des patients pourrait être un instrument utile dans le processus d'amélioration des soins, le présent article souligne un certain nombre de difficultés faisant obstacle à la collecte et à l'utilisation efficaces de ces informations. Il présente une étude de cas du scandale de négligence révélée à Mid-Staffordshire Hospital Trust, de 2005 à 2008, qui illustre la raison pour laquelle une approche centrée sur le patient pour surveiller la prestation des soins est essentielle, mais difficile à mettre en œuvre en pratique. 
INDEX

Keywords: NHS, patients' complaints, Mid-Staffordshire Hospital Trust, health policy

Mots-clés: NHS, patients, plaintes, Mid-Staffordshire Hospital Trust, enquêtes patients

\section{AUTHOR}

LOUISE DALINGWATER

HDEA, Sorbonne-université, Paris 